\title{
ПАНДЕМИЈАТА НА ШПАНСКИОТ ГРИП - ЕДНА НЕНАУЧЕНА ПЕКЦИЈА
}

\section{Апстракт}

Пандемијата на КОВИД-19 која започна минатата година, неминовно, ги натера научниците да се навратат на последната голема пандемија на шпанскиот грип која се случила пред еден век, опфаќајќи ја цุелата Земјина топка и придонела за големи човечки загуби од кои некои држави подолго време морале да закрепнуваат. Слично како и денес, на почетокот опасноста од шпанскиот грип бил потценета, најверојатно и поради воените дејства во Првата светска војна. Војната завриила но вирусот од епидемија прераснал во голема, дотогаш невидена пандемија. Властите споро реагирале на ширенето на овој грип, аздравствениот систем бил иелосно неподготвен да се справи со новата и непозната опасност. На почетокот, дури и лекарите, виролозите и епидемиолозите не можеле да дојдат до заклучок за каков тип на вирус се работи. Сепак, како пандемијата се ширела, така и светот се адаптирал на новите услови. Државите и локалните власти вовеле серија на ограничувачки мерки со цел да го спречат ширенето на вирусот, биле заострени и хигиенските мерки, а било наложено и задолжително носене маски, затворане на трговските објекти, кутурните и образовните установи. Многу нешта од времето на пандемијата на шпанскиот грип се слични со денешните состојби поврзани со КОВИД-19. Шпанскиот грип како што неочкувано се појавил во 1918, така и исчезнал во 1920 година. На научниците им требало повеке од една деценија по завриуване на пандемијата да ја откријат причината за појавата на истата, но и денес сѐ уите има многу непознаници поврзани со шпанскиот грип.

Клучни зборови: пандемија, вирус, шпански грип, мерки, вакцина

За проучувачите на пандемијата на шпанскиот грип е јасно дека тој бил посебен во однос на проширувањето и силината. Грипот ја зафатил Северна Америка и Европа, но исто така изненадувачки се проширил и во дивините на Алјаска и на најоддалечените острови на Тихиот Океан. Се смета дека околу 500000000 луѓе биле заразени од овој вирус или според тогашните бројки тоа изнесувало една третина од вкупната светска популација (Tauenberger:2006, 90). Грипот како вирус не бил непознат пред пандемијата од 1918 година. Уште во антиката Хипократ направил добар опис на овој вирус. Според статистиките и анадизите од 1173 до појавата на шпанскиот грип имало 27 епидемии и пандемиии кои опфатиле разни 
делови од светот (Johnson, 2006:15). Меѓутоа ниту една не била така преносна и толку смртоносна.

\section{Потекло и името на вирусот}

Местото на потеклото на овој вирус и денес е непознато и покрај тоа што бил наречен „шпански грип“ уште во 1918 година (Tauenberger, Morens, 2010: 19). Постојат разни мислења според кои вирусот се појавил во САД, во Кина или пак во Европа каде биле главните фронтови на кои се воделе воените операции за време на Првата светска војна. Кога се говори дека потеклото на овој вирус било од Кина, најчесто тоа се совпаѓа со мислењата дека поранешните искуства со појавата на грипот најчесто биле поврзувани со Далечниот Исток (Radusin, 2012: 813). Постојат научници кои и денес тврдат дека потеклото на вирусот кој довел до пандемијата на шпанскиот грип е сепак од Кина. Наводно, кинеските работници кои патувале во Франција, за време на Првата светска војна би можеле да бидат причината за распространувањето на овој вирус, бидејќи тој веќе постоел во нивната земја (Langford, 2003: 473). Поддржувачите на теоријата дека вирусот потекнувал од Кина, своите аргументи ги поткрепуваат со присуството на респираторна болест, во втората половина на 1917 година, која ги имала елементите на шпански грип и на чума во северните делови на Кина ширејќи се со голема брзина (Hamphries, 2014: 80). Исто така, постоењето на Кинеска болница во која се лекувале работницитие од оваа држава кои биле во Франција се смета за доказ дека овој вирус потекнува од Кина. Во оваа болница помеѓу кинеските работници се појавила смртоносна респираторна болест која наликувала на вирусот. Сепак, истражувањата покажуваат дека потекдото на грипот не може точно и јасно да се одреди. Така британскиот научник Џон Оксфорд смета дека болеста првично се појавила во една британска воена база во Франција во текот на зимата 1916 година (Oxford, 2001: 1857-1859). Кога сме кај британските воени сили на Западниот фронт треба да забележиме дека веќе во март 1918 година, воените лекари и патолози забележале дека кај војниците се појавила блага, но брзораспространувачка треска. (Bresalier, 2013:101). Еркорека смета дека мешавината на војници, животни и 24 типа на отровни воени гасови кои се користеле на Западниот фронт може да бидат причина за појава на епидемијата, која подоцна ќе прерасне во пандемија (Erkoreka, 2009: 191). Од друга страна американецот Бери ја изнел хипотезата дека појавата на шпанскиот грип се случила во областа Хаскел во Сојузната држава Канзас на почетокот на 1918 година. Тој своето тврдење го базирал на сведоштвото на локалниот доктор Лорин Мајнер кој добро ги познавал претходните типови на грип кои се раздикувале од овој по поголемиот број на пациенти, и особено по појавата на сѐ поголемата смртност (Radusin, 2012: 813).

Името на овој вирус било дадено сосема случајно иако Шпанија не била извор на оваа тешка заразна болест. Оваа држава не учествувала во 
Првата светска војна, и тамошниот печат не бил под никаква цензура, кога е во прашање пишувањето за појавата и развојот на новиот тип на грип. Така, во дневниот весник АВС, од 22 мај 1918 година се појавил напис во кој се говорело за постоење на некаков вирус сличен на грипот. Една недела подоцна било објавено дека кралот Алфонсо XIII, шпанскиот премиер и неколку други членови на Владата се разболеле од новиот вирус и така пандемијата била наречена шпански грип (Radusin, 2012: 812). Во оваа насока интересно е да се спомене дека, во истиот период, агенцијата Фабра на Ројтерс му испратила депеша за чудна појава на епидемиски вирус. Освен името шпански вирус, понекогаш бил нарекуван и шпанска госпоѓа (Trill, A., Trilla, G., Daer, 2008: 668). Интересно е да се напомене дека во Шпанија, овој вирус на почетокот бил нарекуван неаполски војник (Soldado de Napoles). Ова име потекнува од музичката оперета La cancion de olvido (Песна на заборавањето) која била изведена за време на првиот бран на опасниот и непознат вирус (Tsoukalas, Kousoulis, Sgantzos, 2016: 24).

Инаку, освен името на вирусот шпански грип, во дитературата може да го сретнеме и француското име La grippe, кое се употребувало во францускиот град Руен, уште кога се појавил овој, дотогаш непознат вирус (Tsoukalas, Kousoulis, Sgantzos, 2016: 23). Најверојатно тоа се должело на фактот што вирусот личел на сезонскиот грип. Но, исто така, е интересно да се забележи, а тоа имало влијание врз развојот на вирусот, дека сѐ до почетокот на август 1918 година, британските лекари, епидемиолози и виролози не го именувале новиот вирус како грип, туку како пирексија од непознато потекло (Bresalier, 2013:102-103).

\section{Развој на пандемијата}

Медицинскиот кадар, виролозите и епидемиолозите од овој период за првпат се соочиде со повеќе бранови на епидемијата од еден вид на грип. За раздика од порано, во текот на епидемијата на шпанскиот грип имало три поголеми и исклучително смртоносни бранови. Првиот бран, кој ги опфатил Европа, Северна Америка и Азија бил во текот на воените операции за време на Првата светска војна од март до априд 1918 година. Вториот бран се случид во периодот од септември до ноември 1918 година, а последниот силен бран се појавил на почетокот на 1919 година (Tauenberger, 2006: 90). Треба да се забележи дека вториот бран бил многу посмртоносен во однос на првиот и тоа се должело на мутацијата на вирусот, предизвикувајќи милиони смртни случаи (Erkoreka, 2009:190). Тука би сакале да напоменеме едно интересно мислење. Во Русија, поради Октомвриската револуција и Граѓанската војна која следувала по овој настан заедно со странската воена интервенција, не биле направени некои истражувања околу пандемијата на шпанскиот грип, но интересно е да се забележи дека според проучувачите во Русија немало трет бран (Морозова, О.М, Трошина, Морозова Е. Н., Морозов А. Н., 2021: 103). Некои сметаат 
дека првиот бран на шпанскиот грип повеќе личел на сезонски бениген грип, сличен на оние кои се појавувале секоја година предизвикувајќи мала смртност помеѓу заболените (Erkoreka, 2009: 193). За раздика од пандемијата од 1890 до 1891 година кога биле потребни повеќе месеци вирусот на тогашниот грип да се прошири низ светот, шпанскиот грип се ширел многу побрзо и истовремено на неколку континенти. Тоа најверојатно била и причината за големата стапка на смртност. Секако, не треба да заборавиме дека појавата на овој тип на грип се поклопила и со воените судири од Првата светска војна, кои сигурно имале влијание и на односот на медицината како наука, но и на вирологијата и епидемиологијата.

Интересно е да забележиме дека на Балканот, поточно на Македонскиот фронт, постојат податоци за појавата на шпанскиот грип помеѓу српските војници. Воениот лекар Александар Радосављевиќ забележал дека во април 1918 година стотина српски војници се соочиле со необично силен вирус кој предизвикал силна пневмонија и смрт кај еден дел од војниците, но и цивилите. Според него причината за појавата на тоа што ќе биде наречен шпански вирус бил контактот на српските војници со француски пекар (Radusin, 2012: 813). Сепак, кога е во прашање српската војска, според Кривошејев, и на островот Крф биле забележани случаи на зараза на војници со новиот вирус. Веќе во јуни и јули биле регистрирани и првите смртни случаи како последица од компликации со белите дробови. (Кривошијев, 2020: 14) Таа несомнено била поврзана со присуството на странските војски на Македонскиот фронт. За жал нема многу податоци колкав број од населението било заразено од овој вирус. Освен податокот што го дава Радосављевиќ за појавата на пандемијата помеѓу српските војници, меѓу кои сигурно имало и мобилизирани Македонци, малку податоци може да најдеме во медицинските анадизи на британските лекари кои биле дел од британските воени единици на Македонскиот фронт, но и тие податоци се однесуваат само за војниците, додека немаме никакви податоци за населението. Сепак, од британските извештаи може да забележиме дека во летото 1918 година веќе имало појава на овој вирус, кој подоцна предизвикал голема смртност помеѓу војниците, кои и така страдале од маларија и колера (Phear, 1920, 90 - 92). По пробивањето на Македонскиот фронт, може да забележиме дека во Велес имало болница во која биле сместени заразените српски војници (Кривошијев, 2020: 15). Кон крајот на октомври 1918 година во Скопје пристигнал и командантот на силите на Антантата, кои го пробиле Македонскиот фронт, Ауј Франше д’Епере, кој во своите мемоари запишал дека во градот имало многу заболени и починати од шпанскиот грип (д’Епере, 2018:113). За бројките околу заразените и починатите во Србија, во тој временски период, немаме точни податоци, бидејќи земјата само што била ослободена од австроунгарската, германската и бугарската окупација. Според еден извештај на британското Министерство за здравство земјата се соочувала со страшна состојба на здравствениот систем, кој речиси да не постоел. Болниците биле во очајна 
состојба, целосно неподготвени да примаат пациенти (Reports, 1919:260). Слична состојба била и во поразената Бугарија, од каде не пристигнувале никакви информации за ширењето на шпанскиот грип (Reports, 1919: 261). Во Грција, на чија територија беше и дел од Македонскиот фронт, во весникот Тесалија на 30 јуни 1918 година биле објавени информации за присуството на шпанскиот грип на грчка територија, а веќе на 23 август Министерството за внатрешни работи издало први информации за новиот вирус (К $\alpha \varrho \alpha \chi \alpha \lambda เ o v, 2009: 37-39)$. За раздика од Србија и Бугарија, имаме некои податоци за бројот на починатите. Во Солун, на пример, во периодот од септември до декември 1918 година, како последица на овој вирус починале 1164 лица, додека во Атина и Пиреа 1619 жители (Reports, 1919: 259-260).

Во поразвиените држави во светот кои биле вкдучени во најголемиот воен судир во дотогашната светска историја - Првата светска војна, тогаш позната како Големата војна, станало јасно дека јавното здравство било целосно неподготвено за пандемијата на шпанскиот грип (SaundersHastings, Krewski, 2016: 5). Еден од поголемите проблеми со кој се соочил јавниот здравствен систем, во текот на оваа пандемија, биле преполните болници и недостатокот од медицински кадар кој исто така бид жртва на оваа пандемија. Болниците морале да го продолжуваат работното време на медицинскиот кадар, да повикуваат студенти на помош, да ги одложуваат останатите медицински услуги, сѐ со цел да се справат со новиот и опасен вирус (Schoch-Spana, 2001: 33). Исто така здравствените власти на помош ги повикале и пензионираните лекари и медицински сестри, а помош била побарана и од сите кои имале некакво искуство во негување болни лица.

Првите анализи за бројот на жртвите од пандемијата на шпанскиот грип ги направид Едвин Џордан во текот на дваесеттите години на минатиот век. Според неговите процени бројот на жртвите на оваа пандемија изнесувал околу 21500000 луѓe (Johnson, Mueller, 2002: 108). Денес, по попрецизни податоци и анализи, бројот на жртвите се проценува на повеќе од 50000000 луѓе, иако и тој не конечен.

Денес кога американските научници пишуваат за големиот број на жртви од шпанскиот грип нагдасуваат дека бројот на починати од овој вирус ги надминувал американските загуби во Првата светска војна, Втората светска војна, како и во војните во Кореја и Виетнам (Radusin, 2012: 813).

Во Велика Британија исто така била голема смртноста на заболените од шпанскиот грип во однос на претходните пандемии. Според официјалните податоци од 1920 година во Англија и во Велс смртноста изнесувала 4,774 \% на 1000 заболени, додека во Шкотска смртноста изнесувала 4,3 $\%$ (Johnson, 2006:69).

Вирусот и на другите континенти предизвикал висока смртност. Ауѓето доживувале вистинска трагедија. Некои оддалечени ескимски населби едноставно биле преполовени или исчезнале (Cevtinić, Savić, 
2018:135). Сдично се случувадо и во Африка. Според податоците 4 \% од жителите на јужноафриканското пристаниште Кејптаун починале како последица на шпанскиот грип, додека во мексиканската држава Чијапас бројот на починатите изнесувал $10 \%$. Во Јапонија починале 300000 жители. Од приложените анализи на бројките на починатите, на 1000000 жители, може да заклучиме дека овој број е далеку поголем на африканскиот континент и во Азија отколку во Европа и во северна Америка (Johnson, Mueller, 2002:110-114). Изворите се полни со страотни податоци за секојдневните случувања по улиците, возовите, домовите. Во јужноафриканското пристаниште Кејптаун, машиновозач за само пет кидометри возење со возот пријавид шест смртни случаи како последица на грипот, а во Австралија еден лекар за само еден ден навел 26 погребни поворки во една улица (Tsoneva, Hristova, 2018: 164). Сепак, научниците забележуваат дека и покрај фактот што вирусот се проширид на сите континенти, со страшни последици по населението, преовдадувачки впечаток е дека тој повеќе ги зафатил Европа, Азија и северна Америка (Tsoukalas, Kousoulis, Sgantzos, 2016: 24). Тоа ни покажува дека треба да се направат поголеми истражувања со цел да се покаже дека оваа пандемија била разурнувачка за целото човештво. Тоа се однесува и за истражувањата во Македонија.

Смртноста на шпанскиот грип носела и демографски промени. Така во Шпанија, земјата според која бил наречен овој вирус, во 1918 година морталитетот кај населението бил највисок во текот на целиот 20 век. Во истата година растот на населението во Шпанија бил негативен како резултат на големата смртност од грипот (A.Trilla, G. Trilla, Daer, 2008: 672). Тоа и било иогично ако се погледне на фактот дека во вториот по големина шпански град Барселона во еден ден умирале и до 1200 граѓани Tsoneva, Hristova, 2018: 164). Пандемијата била најголемиот демографски потрес кој човештвото го доживеало.

\section{Мерки за заштита на населението и спречување ширење на вирусот}

Властите во разни држави од светот преземале мерки со цел да се спречи ширењето на пандемијата на шпанскиот грип која косела сѐ пред себе. Во САД властите забележале дека вирусот масовно се ширел поради присутноста на населението на јавните места. Гдедајќи го тоа, здравствените власти се обиделе да применат мерки на социјална дистанца со дотогаш невидени размери (Tomes, 2010: 48). Сепак, мерките кои биле преземени не давале големи резултати и тоа било признавано од здравствените власти. Особен проблем претставувала забраната за јавно собирање, како и затворањето на некои институции и докали, кое не било проследено со целосно затворање на сите локали и затоа се јавувале проблеми и жалби на оние кои биле затворени. Државата ги затворила училиштата, а бил воведен и карантин. Одредени катодички свештеници, како на пример во Њу Орлеанс се бунтувале поради затворањето на црквите (исто). Мерките 
кои ги преземале властите за затворање на кината и театрите довеле до намалување или исчезнување на приходите на тие што се занимавале со овие дејности, иако и самите граѓани започнале да избегнуваат посети на киносалите и на театрите (Koszarski, 2005: 467). Меѓуутоа како што минувало времето некои од театрите успевале да добијат дозвола повторно да работат, некои пак самоиницијативно ги отвориле салите, имајќи големи финансиски проблеми (исто). Сепак ова затворање, дозволата за работа или самоиницијативното прекршување на законот зависело од град до град и од сојузна држава до држава. На пример, според Кошарски, градот Њујорк никогаш целосно не ги затворил кината и театрите (исто). Државата започнала и кампања преку јавните медиуми да ја подигне свеста на населението за опасноста од шпанскиот грип. Биле објавувани брошури, а се печателе и стрипови и карикатури. Исто така се работело на подигнување на свеста за поголема лична хигиена на населението. Особено се нагласувало дека кашлањето, кивањето, но и плукањето претставуваат сериозна опасност за проширување на вирусот. Се нагласувало дека контактите помеѓу луѓето, особено со оние што биле заразени, биле голема причина за проширување на вирусот. И тоа е една од лекциите кои биле научени во оваа пандемија во САД.

На Балканот може да забележиме дека и во Србија, која покрај огромните човечки и материјални загуби во текот на Првата светска војна, се појавил овој вирус, предизвикувајќи големи проблеми и смртност. Српскиот воен лекар Алекса Савиќ предупредил дека една од причините за брзото ширење на вирусот, освен воените дејства, кои привршиле кон крајот на 1918 година било и собирањето во групи во бегалските логори, касарните, фабриките итн. (Савић, 1918: 5). Тој предложил мерки за колку што е можно запирање на брзото ширење на вирусот. Според него не требало да се контактира со болните, не треба да се оди на места каде има собирање на луѓето како кината, театрите, училиштата, кафеаните. Посебно требало да се внимава на дичната хигиена, со посебен акцент на рацете, грлото и носните шуплини. Слично како и во САД и тој предложид да се внимава со кашлањето, кивањето, но и како што нагласил националниот спорт - плукањето. Тој предложил и носење маски од страна на медицинскиот персонал, но и носење марами од страна на обичните граѓани. Во Грција, во октомври 1918 година, Министерството за внатрешни работи забранило јавни собири, ги затворило училиштата и препорачало одржување хигиена и избегнување контакти со сите лица кои покажувале симптоми на вирусот (Tsoukalas, Kousoulis, Sgantzos, 2016: 24).

Во Италија и во Португалија биле преземени слични мерки. Веднаш по појавата на новиот вирус биле затворени училиштата и јавните објекти, но тоа не секогаш било прифатено од образовните институции. Интересна била и улогата на медиумите во Италија чии известувања за развојот на вирусот и стапката на смртност довеле до конфликтни ситуации. Тоа не можело да помине без последици. Најтиражниот италијански дневен 
весник Corriere della Sera бил принуден од цивилните власти да престане да известува за зголемувањето на бројот на починати од шпанскиот грип, бидејќи на тој начин се зголемувала несигурноста кај населението и се создавала паника (Tinotti, 2013: 257).

Јавните манифестации каде се собирале голем број на граѓани биле откажувани. Во Париз требало да биде одржан спортски натпревар на кој било очекувано присуство на 10000 луѓе. Градските власти го откажале натпреварот со цел да не дојде до уште поголемо ширење на вирусот (исто). Кога е Франција во прашање, треба да се спомене, дека уште на самиот почеток од пандемијата, градоначалникот на Лион, Едуар Ерио, ја разбрал важноста од одржување на хигиената и наредил редовна дезинфекција на трамваите, забранил јавни собири, организирал брзи погреби, додека во црквите наредил светата вода за верниците да се меша со антисептици (Tsoukalas, Kousoulis, Sgantzos, 2016: 24).

Австралија, иако е далечен и изолиран континент, во текот на март 1919 година се соочила со новиот вирус на шпанскиот грип. Како и другите земји, и Австралија, сѐ уште дел од Британската Империја, односно тамошните власти се обиделе да ја спречат пандемијата преку одредени мерки како што биле затворањата на училиштата, театрите, црквите, пабовите. Исто така е интересно да се забележи дека улиците во австралиските градови биле прскани, а населението било обврзано да носи маски на јавните места, како и да внимаваат на хигиената (Curson, McCracken, 2006: 105). Властите биле принудени да воведат и карантин, како и строга контрола на влегувањето на австрадиска територија. Медиумите имале голема улога во справувањето со новата пандемија. Тоа пак, како и во другите земји, предизвикало реакција на граѓаните.

Преземањето раздични мерки од страна на државните и локалните власти не можело да остане без реакција од страна на граѓаните кои, иако биле загрозени, не секогаш ги почитувале мерките, туку и давале отпор кон истите. Така во Сан Франциско била формирана Anti-Mask League, која протестирала против одлуката на градоначалникот за задолжително носење маски (Dolan, 2020: 1-28). Во нејзината активност била вклучена адвокатката и суфражистка Е. С. Харингтон, позната по своето залагање за граѓански и женски права. Движењето против носење на маските довело и до некои интересни ситуации. Некои од управниците на театрите при крајот на пандемијата не сакале да ги обврзат посетителите, глумците и музичарите да носат маски, додека друг дел пак се плашел да не биде обвинет дека ги поддржуваат оние кои јавно се спротивставувале на носењето маски (Koszarski, 2005: 468).

Обидите на државите со одредени мерки да го ограничат движењето и собирањето на населението предизвикало отпор, но и емоционална и психолошка траума. Тоа може да го забележиме дури и во службените гласила на државите. Во „Српске новине“, кои биле службен весник на Кралството Србија, во еден напис за шпанскиот грип било нагласено дека 
овој вирус ги нарушил востановените обичаи и традиции на луѓето. Така се нагласувало дека луѓето се дистанцирале, престанале да се поздравуваат, а во пријателите гледале непријатели и наместо љубезност се препорачувала жестока нељубезност (Српске новине, 1918: 3). Во таа насока може да забележиме дека имало случаи кога продавачите им забранувале на купувачите да влегуваат во продавниците, а целата продажба се одвивала на отворен простор (Tsoneva, Hristova, 2018: 164).

Промената на начинот на живот и ограничувањата наметнати од властите не придонеле да биде запрена пандемијата. Истражувачите заклучиле дека сите мерки кои биле преземени од страна на централните и локалните власти биле задоцнети и некоординирани, а во деловите на светот погодени од воените дејства, мерките биле непрактични, посебно што движењето на воените единици придонело за распространувањето на вирусот (Tinotti, 2013: 257).

Шпанскиот грип и денес се смета за најфаталната пандемија која се случила во човечката историја (Tauenberger, Morens, 2010: 19). Според анализите кои биле направени една од последиците на грипот била големото влијание на смртноста врз економските процеси во државите (Garren, 2007: 20). Освен економските проблеми кои се појавиле поради пандемијата на шпанскиот грип имало и последици врз здравјето на луѓето кои го преживеале грипот, како шизофренија, дијабетес, мозочни и срцеви удари. Денес сѐ уште се прават анализи за последиците врз животот на луѓето од шпанскиот грип. Сѐ повеќе се заклучува дека овој вирус предизвикал нешто што порано било незамисливо. Најголемиот број на починати од шпанскиот грип во текот на 1918 година, според податоците до кои стигнале научниците, бил од секундарната бактериска пневмонија. Изненадувачки била големата смртност помеѓу младите, кои претходно не страдале толку од другите типови на грип (Tauenberger, 2006: 91). Посебно голема смртност имало во текот на 1918 година помеѓу младите на возраст од 20 до 40 години, карактеристична била брзата смрт во рок од неколку часа од болеста (Tsoneva, Hristova, 2018: 161).

Според анализите може да се заклучи дека овој вирус ги опфатил сите без раздика на класа, пол, раса, нација со сите свои последици (Johnson, 2006: 96). Така меѓу починатите од шпанскиот грип биле францускиот поет Гијом Аполинер, германскиот социолог Макс Вебер, Софи Халбершатд Фројд, ќерка на Сигмунд Фројд, францускиот драматург Едмон Ростан, додека некои успеале да преживеат како францускиот генерал Жозеф Жофре и идниот американски претседател Френклин Делано Рузвелт (Tsoukalas, Kousoulis, Sgantzos, 2016: 26). Кривошејев забележува и еден парадокс, особено во Србија. Иако урбаните средини биле повеќе зафатени од оваа пандемија, сепак смртноста била поголема во руралните области поради пониското културно ниво на населението во руралните делови, начинот на живот и послабо развиената хигиенска и здравствена култура (Кривошејев, 2020: 25). 
Може многу да се пишува за појавата на шпанскиот грип и за неговото ширење, како и по прашањето на преземените мерки за спречување на неговото ширење и реакцијата на јавноста против истите, но сепак една работа може да се забележи, а е иста како и со денешниот опасен вирус КОВИД-19, а тоа е потценувањето на опасноста од вирусот на самиот почеток на неговата појава, како и за време на брановите на неговото ширење. Како што забележавме погоре едно од мислењата за неговата појава е дека истиот потекнува од САД. Мошне интересно е да забележиме дека токму во оваа држава, на почетокот од ширењето на вирусот не било посветено доволно внимание на истиот. Така, во познатото списание на Американската медицинска асоцијација, пролетниот бран воопшто не бил запишан ниту во индексот на списанието (Tsoukalas, Kousoulis, Sgantzos, 2016: 24) Во правец на потценувањето на опасноста од новиот вирус, барем кога САД се во прашање ни говорат и следните примери. На почетокот од епидемијата, која прераснала во пандемија, во споменатата држава многумина од областите кои не биле зафатени, во таа фаза, од новиот опасен вирус, сметале дека истиот бил една обична неприлика, а не смртоносна болест. Па, во некој весник, можело да се прочита дека шпанскиот грип е најверојатно обичен грип со малку доматен сос на него (Dicke, 2015:199). Меѓутоа доматниот сос се покажал како страшна шегобијна грешка во потценувањето на опасноста од новиот вирус. Опасноста многу доцна била разбрана, таква каква што била, и затоа службите на јавното здравство низ САД изгубиле недели во организациска смисла што резултирало со голем број на починати пациенти (Dicke, 2015:200).

\section{Барање лек за вирусот}

Брзиот и жесток развој на шпанскиот грип ги натерало научниците да бараат начин што побрзо да биде направена вакцина за овој вирус, дотогаш непознат во историја и по силинита и по големата смртност. Истражувањата покажуваат дека докторите на почетокот имале тешкотии да го дијагностицираат новиот вирус, често правејќ́и грешка сметајќи дека заболениете имале настинка, колера или бубонска чума. Освен проблемите кои се јавиле околку дијагностицирањето на вирусот, лекарите давале и погрешна терапија која доведувала до смртни последици на заболените. Така употребата на аспиринот, за време на врвот на пандемијата во 1918 година, се покажала како посебно токсична, која предизвикала голема смртност, посебно кај помладите (Starko, 2009: 1409). Сепак брзиот развој на вирусот, неговото мутирање и големата смртност налагале брзо да се бара лек за истиот. Многу брзо започнале да се користат искуствата и откритијата на Яуј Пастер, кои помогнале во справување со други болести. На почетокот погрешно се верувало дека овој вид на грип бил предизвикан од пфајферовата бактерија, но набрзо истражувањето на францускиот научник Шарл Жил Анри Никол открило дека грипот бил предизвикан од мал 
микроорганизам кој не можел да биде виден со тогашните средства за истражување (Radusin, 2012: 813). Дури и денес кога постои вакцина за грип, некои истражувачи сметаат дека овој вирус сѐ уште претставува мистерија.

Во Австралија биле правени обиди да се произведе вакцина, користејќи слуз од плунката, како и комбинација на стрептокока и стафилокока (Curson, McCracken, 2006: 105). Овој нивен обид завршил со неуспех. Слични обиди биле направени и во британската армија, чии здравствени служби воделе интересна расправија каква и кој тип на вакцина требало да биде употребен и дали биле неопходни две дози за целосна заштита (Bresalier, 2013:113-122).

Вистинското откривање на вирусот кој е познат како грип се случило дури по завршувањето на пандемијата на шпанскиот грип. Британските научници Вилсон Смит. Кристофер Ендрујс и Патрик Леидло успеале да го изолираат овој вирус во 1933 година, користејќи го успехот на американскиот виролог Ричард Шоуп, кој две години порано успеал да го изодира и идентификува свинскиот грип (Johnson, 2006: 21). Џонсон смета дека доцното откривање и изолирање на вирусот грип или инфлуенца се должело на повеќе фактори како на техничките причини, тешкотиите во култивирањето на вирусот инфлуенца, како и користењето на Коховите постулати и практичните резултати во бактериологијата на Ауј Пастер и Џозеф Иистер, кои претставувале пречка во барањето на вирусите (исто). Меѓутоа, користењето на новите електронски микроскопи овозможило да се гледа вирусот и во таа насока Френк Мекферлејн Барнет во 1935 година го култивирал вирусот во кокошкино јајце (Tsoukalas, Kousoulis, Sgantzos, 2016: 26). Целиот овој напредок на полето на техниката, медицината и вирологијата овозможил кон крајот на триесеттите и почетокот на четириесеттите години на 20 век медицинската наука конечно да стигне до посакуваната цел - вакцина за грипот. Успехот се должел на паралелните напори на Џонас Салк и Томас Френсис кои успеале да направат вакцина за грип (Saunders - Hastings, Daniel Krewski, 2016: 6).

Откривањето на вакцината за грип не значело дека научниците во тој период го знаеле и изворот и типот на вирусот кој ја предизвикал глобалната пандемија на шпански грип. Дури во 1995 година група научници, користејќи архивски материјали, започнале подетално истражување за да ја откријат геномската структура на шпанскиот грип (Željko Cvetinić, Vladimir Savić, 2020: 137). По извесен период на истражување тие успеале да откријат дека пандемијата на шпанскиот грип била предизвикана од вирусот инфлуенца А од подтипот H1N1. Според нив изворот на овој вирус скоро сигурно потекнувал од птиците, а водните птици се резервоар за сите познати вируси на инфлуенца (исто). Меѓутоа дали навистина загатката на шпанскиот грип е целосно решена. Јас не сум медицинско лице, ниту пак виролог. Затоа тука ќе го искористам мислењето на Гарсија Састра и на Витли кои сметаат дека и покрај големите откритија сѐ уште не е јасна вирулентноста на вирусот кој предизвика огромна човечка траге- 
дија (Garcia-Sastra, Whitley,2006: 5127). Според нив остануваат прашањата за антигенот, патогеноста и имунитетот за вирусот кој ја предизвика најголемата пандемија во историјата (исто, 5130). Сдично на нив размислуваат Моренс и, веќе добропознатиот, Фаучи кои во една своја студија за шпанскиот грип забележале дека многу прашања за овој вирус сѐ уште не се одговорени, посебно за потекдото, необичните епидемиолошки карактеристики, како и причините за смртноста (Morens, Fauci, 2007: 1018-1019). Ова покажува дека колку и да напреднала науката и технологијата, човекот сѐ уште не може да најде одговор на многу прашања кои произдегуваат од минатите епидемии и пандемии. Забележавме во оваа студија дека многу нешта од пандемијата на шпанскиот грип дичат со денешната пандемија на КОВИД-19, и тука лежи еден од одговорите на многуте прашања кои произлегуваат од тоа што ни се случува денеска. Сепак, засега, природата е посилна од човекот. 


\section{Литература}

Д’Епере, Луј Франше, 2018, Мемоари. Солунски фронт, Србија, Балкан, Прометеј, Нови Сад

Савић, Алекса, 1918, Инфлуенца, Војна штампарија, Солун

Сриске новине, г. LXXXV, бр. 126, 23 октобра 1918

Кривошејев, Владимир, 2020, Шпанска смрт: Прилог проучавања последице пандемије шпанске грознице у Србији, Културна полиса, 2. XVII, (2020), бp.43, 11-28

Морозова, О.Н, Трошина, Т.И., Морозова, Е. Н., Морозов, А.Н., 2021, Пандемия испанки 1918 года в Росии. Вопросы 100 лет спустя, Journal of Microbiology, epidemiology and immunobiology, 95-106

Bresalier, Michael 2013, Fighting flu: Military pathology, vaccines and the conflicted identity of the 1918-1919 pandemic in Britain, Journal of the History of Medicine and Allied sciences, v. 68/1, 87-128

Curson, Peter, McCracken, Kevin, 2006, An Australian perspective of the 19181919 Influenza pandemic, NSW Public Health Bulletin, v. 17/7-8, 103-107

Cvetinić Željko, Savić Vladimir, Prije 100 godina španjolski grip „majka“ svih pandemija poharala je svijet, Vetrinarska stanica, v. 49-5, 2018

Dicke, Tom, 2015, Waiting for the flu: Cognitive inertia and the Spanish inluenza pandemic of 1918-1919, Journal of History of Medicine and Allied Sciences, v. $70 / 2,195-217$

Dolan, Brian, 2020, Unmasking history: Who was behind Anti-Mask League protests during the 1918 Influenza epidemic in San Francisco, Perspectives in Medical humanities, 1-28

Erkoreka Anton, Origins of the Spanish Influenza pandemic (1918-1920) and its relation with the First World War, Journal of Molecular and Genetic Medicine, v. 3/2, 2009

Garcia-Sastra, Adolfo, Whitley, Richard, J., 2006, Lessons learned from reconstructing the 1918 Influenza pandemic, The Journal of infectious deseases, $v .194,5127-5132$

Garren, Thomas, 2007, Economic effects of the 1918 Influenza pandemic. Implications for a Modern-day pandemic, Federal Reserve Bank, St. Louis, November

Humphries Mark Osborne, Paths of infection: The First World War and the Origins of the 1918 Influenza pandemic, War in History, v.21/1, 2014

Johnson Niall, Mueller Juergen, Updating the Accounts: Global mortality of the 1918-1920 "Spanish" Influenza pandemic, Bulletin of the History of Medicine, 76/1, 2002

Johnson Niall, Britain and the 1918-19 Influenza pandemic. A dark epilogue, Routledge, London \& New York, 2006 
Koszarski, Richard, 2005, Flu season: "Moving picture world" Reports on Pandemic influenza, 1918-1919, Film History, v. 17/4,466-485

Langford Christopher, 2003, Did the 19181-19 Influenza Pandemic originate in China?, Population and Development Review, v. 31/3,

Morens, David M., Fauci, Anthony S., 2007, The 1918 Influenza pandemic: Insights for $21^{\text {st }}$ Century, The Journal of Infectious Diseases, v. 195/7, 10181028

Oxford J.S., The so-called great Spanish influenza pandemic of 1918 may have originated in France in 1916, Philos Trans Soc. Lond. B. Biol Sci 356, 2001

Phear, Arthur G., 1920, Medical experiences in Macedonia and Caucasus, Occasional lecture, March, 26,

Radusin Milorad, The Spanish flu - Part I: the first wave, Vojnosanitetski pregled, 69/9, 2012

Reports on Public Health, 1919, v. 4, Ministry of Health, London

Saunders - Hastings Patrick R., Krewski Daniel, Reviewing the History of Pandemic Influenza: Understanding patterns of emergence and transmission, Pathogens, 66/5,2016

Schoch - Spana Monica, "Hospital's full - up": The 1918 Influenza Pandemic, Public Health Report, v. 116/2, 2001

Starko, Karen, 2009, Salicylates and Pandemic influenza mortality. 1918-1919 Pharmacology, Pathology and Historic evidence, Clinical infestions deseases, v. 49/9, 1405-1410

Tauenberger Jeffrey K., 2006, The origin and virulence of the 1918 "Spanish" influence virus, Proceedings of the American Philosophical Society, v. 150/1, 2006

Tauenberger Jeffrey K., David, Morens M., 2010, Influenza: The one and future pandemic, Public Health Reports, v. 125/3

Tinotti Eugenia, Lessons from the History of Quarantine, from Plague to Influenza A, Historical review, 19/2, 2013

Tomes Nancy, "Destroyer and Teacher": Managing the mass during the 19181919 influenza pandemic, Public Health reports, v. 125, 2010

Trilla, Antoni, Trilla Guillem, Daer, Carolyn, 2008, The 1918 "Spanish Flu" in Spain, Clinical Infectious Disease, v. 47/5

Tsoneva, Lilyana, Hristova, Irina, 2018, Spanish flu pandemic, in: Karaganova Irina, Konstantinova Daniela (ed.), Helath promotion and Social work, health care. Proceedings, v. 57, series 8.4, University of Ruse, 161-165

Tsoukalas, Gregory, Kousoulis, A., Antonis, Sgantzos, N. Markos, 2016, The 1918, Spanish Flu Pandemic, the origins of the H1N1-virus strain, a Glance in History, European Journal of Clinical and Biomedical Sciences, $v$. $2(4), 23-28$

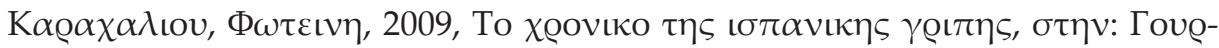

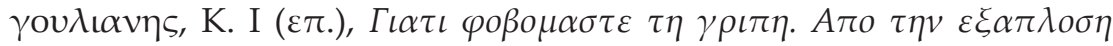

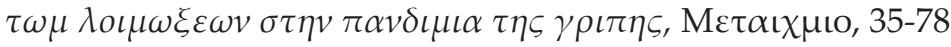

